\title{
MANAGEMENT PRACTICES, WORK- LIFE BALANCE, AND PRODUCTIVITY: A REVIEW OF SOME RECENT EVIDENCE
}

\author{
NICK BLOOM \\ Stanford University, Centre for Economic Performance and NBER \\ JOHN VAN REENEN \\ Centre for Economic Performance, London School of Economics, and CEPR ${ }^{1}$
}

\begin{abstract}
Increasing product-market competition is believed to be a driving force behind higher productivity. However, even those critics of globalization who accept this argument claim that there is a hard trade-off because tougher competition comes at the price of reducing work-life balance (WLB). Optimists, by contrast, argue that competition can spur better WLB practices and therefore higher productivity, so there is a 'win-win' situation. To address this issue we use an innovative survey tool to collect the first international data on management practices and WLB practices, surveying 732 medium-sized manufacturing firms in the USA, France, Germany, and the UK. We find that the USA has the best management practices but the worst work-life balance. When we look within countries, however, we reject the pessimistic 'trade-off' model. First, WLB outcomes are significantly associated with better management, so that well-run firms are both more productive and offer better conditions for their employees. Second, tougher competition increases average management quality but does not negatively affect employees' working environment. As with many other studies, better WLB practices are associated with significantly higher productivity. This relationship disappears, however, after controlling for the overall quality of management.
\end{abstract}

\section{INTRODUCTION}

Product-market competition is generally believed to be an important factor in increasing productivity.
Although this competition effect is also believed to operate through improving management practices, there is little statistical evidence on the role of competition in improving management. Further-

\footnotetext{
${ }^{1}$ E-mail addresses:nbloom@stanford.edu;j.vanreenen@1se.ac.uk
}

We would like to thank AIM, the Anglo-German Foundation, and the ESRC for their generous financial support. This draws on joint work with Toby Kretschmer, to whom we are very grateful for numerous comments. Many seminar participants, Andy Neely, and an anonymous referee have also offered helpful remarks. 
more, if competition is beneficial for productivity through improving management, why is there so much popular resistance to globalization and liberalization, especially in Continental European countries? One possibility is that improved management practices and higher productivity come at the expense of making workers' lives miserable through eroding their work-life balance (WLB). AngloSaxon management practices may raise productivity but only at the expense of wellbeing at work. A contrasting view is that competition may actually be beneficial for workers. If unenlightened managers fail to meet the aspirations of their workers to match a good work-life with a decent home-life, their businesses will suffer. In this 'win-win' view of the world, espoused by many in the human resource management (HRM) literature, ${ }^{2}$ competition could stimulate better WLB practices that will help raise productivity. For example, Tony Blair, the UK Prime Minister, stated: 'The UK has shown it is possible to have flexible labour markets combined with . . . family friendly policies to help work/life balance. ... The result has been higher growth, higher employment and low unemployment.' ${ }^{3}$

We have pioneered a line of research that seeks to shed empirical light on these issues through developing an innovative survey tool that collects robust measures of management practices and WLB in over 700 firms across four countries. The management practices we cover combine elements of shopfloor operations (e.g. lean manufacturing), monitoring (e.g. process tracking), targets (e.g. stretching or not), and people management (e.g. promotions and pay policies). The WLB measures include parttime work flexibility, time off for family duties, childcare support and the ability to work from home. Our methods employ a combination of the quantitative skills of survey design and the qualitative skills of the case-study approach. We show that the management data we collect are robust and extremely useful in tackling a variety of classic questions in the literature.
Our results show that across countries US firms appear to be the best managed and British firms the worst managed. German firms come second and French firms third. However, US firms appear to have the worst WLB in terms of such things as job flexibility and childcare, whereas French firms have the best WLB scores. So casual empiricism across countries would appear to favour the 'trade-off' model between competition and WLB. What is striking, however, is the huge inter-firm variation in management practices within all countries in our data. We exploit this within-country variation to show that the trade-off view is inconsistent with the evidence. In particular, we find the following.

(i) Good management practices and better WLB practices are positively correlated.

(ii) Tougher product-market competition significantly raises average management quality but does not reduce WLB.

(iii) There is a robust, positive, and significant correlation of productivity (and other measures of firm performance) with better management.

(iv) There is a positive and significant correlation of productivity with WLB, but this disappears when we control for management practices.

Taken together, these findings are not consistent with the simple trade-offmodel. Competition stimulates higher productivity through improving management practice, but it does not have the downside of reducing work-life balance. However, neither do our results give unequivocal support for the win-win model - the positive association between productivity and WLB is not robust to controlling for management practices.

The structure of the paper is as follows. In section II, we discuss simple 'models' of management practices and firm performance. In section III, we

\footnotetext{
${ }^{2}$ Delaney and Huselid (1996); Huselid et al. (1997); Konrad and Mangel (2000); Perry-Smith and Blum (2000); Guthrie (2001); Gray (2002); Budd and Mumford (forthcoming). This seems stronger in environments requiring more flexibility-for example, in high-technology industries (Arthur, 2003) or in highly differentiated firms (Youndt et al., 1996; Lee and Miller, 1999; Guthrie et al., 2002).

${ }^{3}$ Toby Helm and David Rennie, 'Blair Attack on "Out-of-date" Chirac', Daily Telegraph, 25 March 2005(available at http:/ /www.telegraph.co.uk/news/main.jhtml?xml=/news/2005/03/25/weu25.xml\&sSheet=/news/2005/03/25/ixnewstop.html).
} 
provide a detailed discussion of our datasets and the procedures used to collect these. In section IV we offer some descriptive statistics and in section $\mathrm{V}$ we discuss our results. Finally, in section VI, we provide some concluding comments. A detailed set of empirical appendices then follows.

\section{MODELLING APPROACH}

Consider a simple approach of characterizing the above approaches:

$$
\begin{aligned}
& w=f(X, M, D) \\
& y=g(X, M, D)
\end{aligned}
$$

where $w=$ work-life balance outcomes and $y=$ (total factor) productivity outcomes. $X$ is an index of 'good' WLB practices ( such as childcare flexibility and subsidies) and $M$ is an index of 'good' management practices (such as better shop-floor operations or performance-based promotion systems). We model these as being composite measures of several underlying practices so $M=m\left(M_{1}, M_{2}\right.$, $\left.M_{3}, \ldots\right)$ and $X=x\left(X_{1}, X_{2}, X_{3}, \ldots\right)$. Finally, $D$ is other control variables, such as firm size, firm age, industry effects, and country dummies, etc.

We would expect that better management practices should be associated with improved productivity so $(\partial y / \partial M) \geq 0$ (see Bloom and Van Reenen (2006) for extensive evidence). We would also expect that better WLB practices should be associated with improved reported WLB outcomes so $(\partial w / \partial X) \geq 0$ : this is the first thing that we examine empirically in the paper.

What is much less clear are the cross-partial derivatives in equations (1) and (2). Pessimists argue that improved WLB is costly in terms of productivity and will therefore be heavily resisted by an employerwhich is one reason for tough labour regulation. ${ }^{4}$ In the context of equation (1), this implies $(\partial y / \partial X) \leq 0$. Similarly, pessimists argue that 'Anglo-Saxon' management practices come at the expense of WLB so $(\partial w / \partial M) \leq 0$.
By contrast, optimists from some parts of the HRM field often argue for a win-win view that improving WLB practices will increase productivity as it boosts employee well-being - leading to improved recruitment and retention (e.g. of women) and better morale and motivation. In this case, $(\partial y / \partial X) \geq 0$. They generally also argue that better management tends to be complementary with better WLB practices and, at a minimum, there is no obvious reason why they should be strong substitutes. Thus, $(\partial w /$ $\partial M) \geq 0$.

These cross partials are with respect to endogenous variables chosen by firms, so it is not obvious how to interpret these relationships. Nevertheless, the examination of the correlations with new data should be informative. More directly, however, we also consider the more fundamental drivers of these practices. Consider a set of factors $Z\left(=Z_{1}, Z_{2}, Z_{3}\right.$, ... ) that may exogenously affect the practices. We model management practices and WLB practices as functions of the exogenous variables as:

$$
X=h(Z, D) \text { and } M=j(Z, D) \text {. }
$$

We are particularly interested in product-market competition as one of the elements of $Z$. Under the pessimistic view tougher product competition caused by globalization, liberalization, and new technologies may increase productivity through improved management practices $(\partial M / \partial Z) \geq 0$, but this will be at the expense of worse WLB practices and outcomes, i.e. $(\partial X / \partial Z) \leq 0$. We examine these predictions directly in the empirical work. The optimists also view competition as a force promoting better management practices, but, by contrast with the pessimists, they argue that this should increase the use of good WLB practices. This is because, in their view, firms are making mistakes by not introducing better WLB practices, and competition should make such profit-sacrificing strategies more costly.

To summarize, these two models provide a set of predictions laid out in Table 1 that we subsequently take to the data. Of course, there can be 'hybrid' positions between these positions. In short, we find

\footnotetext{
${ }^{4}$ Even if WLB practices improved productivity, they might still be resisted by employers if the costs of implementing these policies were more than their productivity benefits.
} 
Table 1

Empirical Predictions of Different Models

\begin{tabular}{|c|c|c|c|c|c|c|}
\hline & (1) & (2) & (3) & (4) & (5) & (6) \\
\hline & $\begin{array}{c}\text { WLB } \\
\text { outcomes }\end{array}$ & $\begin{array}{c}\text { WLB } \\
\text { outcomes }\end{array}$ & Productivity & Productivity & $\begin{array}{c}\text { WLB } \\
\text { practices }\end{array}$ & $\begin{array}{c}\text { Managemen } \\
\text { practices }\end{array}$ \\
\hline & $\begin{array}{c}\text { Derivative } \\
\text { w.r.t. } \\
\text { WLB } \\
\text { practices }\end{array}$ & $\begin{array}{l}\text { Derivative } \\
\text { w.r.t. } \\
\text { management } \\
\text { practices }\end{array}$ & $\begin{array}{l}\text { Derivative } \\
\text { w.r.t. } \\
\text { WLB } \\
\text { practices }\end{array}$ & $\begin{array}{l}\text { Derivative } \\
\text { w.r.t. } \\
\text { management } \\
\text { practices }\end{array}$ & $\begin{array}{c}\text { Derivative } \\
\text { w.r.t. } \\
\text { competition }\end{array}$ & $\begin{array}{c}\text { Derivative } \\
\text { w.r.t. } \\
\text { competition }\end{array}$ \\
\hline Pessimist & Positive & Negative & Negative & Positive & Negative & Positive \\
\hline Optimist & Positive & Positive & Positive & Positive & Positive & Positive \\
\hline
\end{tabular}

Note: w.r.t. is with respect to.

Source: Bloom et al. (2006).

that the evidence is inconsistent with the negative view: management practices are positively associated with WLB outcomes and there is no evidence that competition reduces WLB for workers. Nevertheless, the positive view does not receive unambiguous support: although better management and better WLB do sometimes go together, the positive correlation between WLB and productivity found elsewhere in the literature is not robust. Once we control for management we find no association of WLB with productivity. We find the evidence supports a hybrid view between the optimistic and pessimistic extremes.

\section{DATA}

To investigate these issues we first have to construct robust measures of WLB, management practices, and competition. We discuss the collection of management and WLB data first (which was undertaken using a new firm survey tool) and then the collection of productivity and competition data, which were taken from more standard firm and industry data sources.

\section{(i) Scoring WLB and Management Practices}

Measuring WLB and management practices requires codifying these concepts into something widely applicable across different firms. This is a hard task as WLB and good management are difficult to define. To do this we combined questions that have been used previously in the: (i) Workplace Employment Survey (WERS); (ii) a management practice evaluation tool developed by a leading international management consultancy firm; and (iii) the prior economics and management academic literature.

\section{Work-life balance}

In Appendix A2, we detail the Human Resources Interview guide that was used to collect a range of detailed WLB practices and characteristics from firms. We collected three types of key data.

- The first was the WLB perceptions data of individuals on their own firms' WLB versus that of other firms in the industry. This was used as our WLB outcome measure, defined as the response to the question: 'Relative to other companies in your industry how much does your company emphasize work-life balance?', scored as: much less (1); slightly less (2); the same (3); slightly more (4); much more (5).

- The second was the WLB policies/practices data on key variables including childcare flexibility, home-working entitlements, part-time to full-time job flexibility, job-sharing schemes, and childcare-subsidy schemes. This was used to construct our WLB practice measure defined as the average $z$-score ${ }^{5}$ from the five

${ }^{5}$ For comparability to the management z-score this WLB z-score (and the management z-score) were both re-normalized to zero mean with standard deviation one. Hence, the coefficients on both the management and WLB practice $z$-scores in the tables of results both respond to one standard deviation change in both measures. 
questions: 'If an employee needed to take a day off at short notice due to child-care problems or their child was sick how do they generally do this?'; and the entitlements to 'working at home in normal working hours', 'switching from fulltime to part-time work', 'job-sharing schemes', and 'financial subsidy to help pay for childcare'. These are all ranked on a scale of 1 to 5 .

- The third was workforce characteristic data on key variables including average employee age, hours, holidays, and proportion female, plus a full set of conditioning variables on skills (the proportion of college educated), training, and unionization. We used these data as a control for heterogeneity across firms.

\section{Management practices}

In Appendix A1, we detail the practices and the questions in the same order as they appeared in the survey, describe the scoring system, and provide three anonymous responses per question. These practices can be grouped into four areas: operations (three practices), monitoring (five practices), targets (five practices), and incentives (five practices). The operations management section focuses on the introduction of lean manufacturing techniques, the documentation of process improvements, and the rationale behind introductions of improvements. The monitoring section focuses on the tracking of the performance of individuals, reviewing performance (e.g. through regular appraisals and job plans), and consequence management (e.g. making sure that plans are kept and appropriate sanctions and rewards are in place). The targets section examines the type of targets (whether goals are simply financial or operational or more holistic), the realism of the targets (stretching, unrealistic, or non-binding), the transparency of targets (simple or complex), and the range and interconnection of targets (e.g. whether they are given consistently throughout the organization). Finally, incentives (or people management) include promotion criteria, pay and bonuses, and fixing or firing bad performers, where best practice is deemed to be an approach that gives strong rewards for those with both ability and effort. A subset of the practices has similarities with those used in studies on HRM practices, such as Ichniowski et al. (1997), Black and Lynch (2001), and Bartel et al. (2004).

Since the scaling may vary across practices in the econometric estimation, we convert the scores (from the $1-5$ scale) to z-scores by normalizing by practice to mean zero and standard deviation one. In our main econometric specifications, we take the unweighted average across all z-scores as our primary measure of overall managerial practice, ${ }^{6}$ but we also experiment with other weightings schemes based on factor analytic approaches.

There is legitimate scope for disagreement over whether all of these measures really constitute 'good practice'. Therefore, an important way to examine the externality validity of the measures is to examine whether they are correlated with data on firm performance constructed from company accounts and the stock market.

\section{(ii) Collecting Accurate Responses}

With this evaluation tool we can, in principle, provide some quantification of firms' WLB and management practices. However, an important issue is the extent to which we can obtain unbiased responses to questions from firms. In particular, will respondents provide accurate responses? As is well known in the surveying literature (see, for example, Bertrand and Mullainathan, 2001) a respondent's answer to survey questions is typically biased by the scoring grid and anchored towards those answers that they expect the interviewer thinks is 'correct'. In addition, interviewers may themselves have preconceptions about the performance of the firms they are interviewing and bias their scores based on their ex ante perceptions. More generally, a range of background characteristics, potentially correlated with good and bad managers, may generate some kinds of systematic bias in the survey data.

To try to address these issues we took a range of steps to obtain accurate data.

- First, the survey was conducted by telephone without telling the managers they were being scored. ${ }^{7}$ This enabled scoring to be based on

\footnotetext{
${ }^{6}$ This management z-score was then re-normalized to zero mean and standard deviation one.

7 This survey tool has been passed by Stanford's Human Subjects Committee. The deception involved was deemed acceptable because it is: (i) necessary to get unbiased responses; (ii) minimized to the management-practice questions and is temporary (we send managers debriefing packs afterwards); and (iii) presents no risk as the data are confidential.
} 
the interviewer's evaluation of the actual firm practices, rather than the firm's aspirations, the manager's perceptions, or the interviewer's impressions. ${ }^{8}$ To run this 'blind' scoring we used open questions (i.e. 'Can you tell me how you promote your employees?'), rather than closed questions (i.e. 'Do you promote your employees on tenure [yes/no]?'). These questions target actual practices and examples, with the discussion continuing until the interviewer could make an accurate assessment of the firm's typical practices. Typically, about three or four questions were needed to score each practice.

- Second, the interviewers did not know anything about the firm's financial information or performance in advance of the interview. This was achieved by selecting medium-sized manufacturing firms and by providing only firm names and contact details to the interviewers (but no financial details). These smaller firms would typically not be known by name and are rarely reported in the business media. The interviewers were specially trained graduate students from top European and US business schools, with a median age of 28 and 5 years' prior business experience in the manufacturing sector. ${ }^{9}$ All interviews were conducted in the manager's native language.

- Third, each interviewer ran over 50 interviews on average, allowing us to remove interviewer fixed effects from all empirical specifications. This helped us to address concerns over inconsistent interpretation of categorical responses (see Manski, 2004), standardizing the scoring system.

- Fourth, the survey instrument was targeted at plant managers, who are typically senior enough to have an overview of management practices but not so senior as to be detached from day-today operations of the enterprise.

- Fifth, a detailed set of information was also collected on the interview process itself(number and type of prior contacts before obtaining the interviews, duration, local time-of-day, date, and day-of-the week), on the manager (gender, seniority, nationality, company and job tenure, internal and external employment experience, and location), and on the interviewer (we can include individual interviewer-fixed effects, time-of-day, and a subjective reliability score assigned by the interviewer). Some of these survey controls are significantly informative about the management score (see Table C1), ${ }^{10}$ and when we use these as controls for interview noise in our econometric evaluations the coefficient on the management score typically increased (see Bloom and Van Reenen, 2006).

\section{(iii) Obtaining Interviews with Managers}

The interview process took about 50 minutes on average, and was run from the Centre for Economic Performance at the London School of Economics. Overall, we obtained a high response rate of 54 per cent, which was achieved through four steps.

- First, the interview was introduced as 'a piece of work' ${ }^{11}$ without discussion of the firm's financial position or its company accounts, making it relatively uncontroversial for managers to participate. Interviewers did not discuss financials in the interviews, both to maximize the participation of firms and to ensure our interviewers were truly 'blind' on the firm's financial position.

- Second, questions were ordered to lead with the least controversial (shop-floor management) and finish with the most controversial

\footnotetext{
${ }^{8}$ If an interviewer could not score a question it was left blank, with the firm average taken over the remaining questions. The average number of un-scored questions per firm was 1.3 per cent, with no firm included in the sample if more than three questions were un-scored.

${ }^{9}$ Our thanks to the interview team of Johannes Banner, Michael Bevan, Mehdi Boussebaa, Dinesh Cheryan, Alberic de Solere, Manish Mahajan, Simone Martin, Himanshu Pande, Jayesh Patel, and Marcus Thielking.

${ }^{10}$ In particular, we found the scores were significantly higher for senior managers, when interviews were conducted later in the week and/or earlier in the day. Scores were highest, on average, for senior managers on a Friday morning and lowest for junior managers on a Monday afternoon. By including information on these characteristics in our analysis, we explicitly controlled for these types of interview bias.

${ }^{11}$ Words like 'survey' or 'research' should be avoided as these are used by switchboards to block market research calls.
} 
(pay, promotions, and firings). The WLB questions were placed at the end of the interview to ensure the most candour in the response to this.

- Third, interviewers' performance was monitored, as was the proportion of interviews achieved, so they were persistent in chasing firms (the median number of contacts each interviewer had per interview was 6.4). The questions were also about practices within the firm that any plant manager could respond to, so there were potentially several managers per firm who could be contacted. ${ }^{12}$

- Fourth, written endorsement of the Bundesbank (in Germany) and the Treasury (in the UK), and a scheduled presentation to the Banque de France helped demonstrate to managers this was an important exercise with official support.

\section{(iv) Sampling Frame and Additional Data}

Since our aim was to compare across countries, we decided to focus on the manufacturing sector, where productivity is easier to measure than in the nonmanufacturing sector. We also focused on mediumsized firms, selecting a sample where employment ranged between 50 and 10,000 workers (with a median of 700). Very small firms have little publicly available data. Very large firms are likely to be more heterogeneous across plants, and it would be more difficult to get a picture of managerial performance in the firm as a whole from one or two plant interviews. We drew a sampling frame from each country to be representative of medium-sized manufacturing firms and then randomly chose the order of which firms to contact (see Appendix B for details). We also excluded any clients of our partnering consultancy firm from our sampling frame. ${ }^{13}$

Comparing the responding firms with those in the sampling frame, we found no evidence that the responders were systematically different to the non-responders on any of the performance measures. They were also statistically similar on all the other observables in our dataset. The only exception was on size, where the firms that responded were slightly larger than the average of those in the sampling frame.

\section{(v) Evaluating and Controlling for Potential Measurement Error}

To quantify possible measurement error in the WLB and management practice scores obtained using our survey tool, we performed repeat interviews on management practice data on 64 firms - contacting different managers in the firm, typically at different plants, using different interviewers. To the extent that our measures are truly picking up general company-wide practices, these two scores should be correlated, while to the extent that our measures are driven by noise, these should be independent.

There is a high correlation between the average firm-level management scores from the first interview and the second interview (correlation 0.734 with p-value 0.000). Furthermore, there is no obvious (or statistically significant) relationship between the degree of measurement error and the absolute score. That is to say, high and low scores appear to be as well measured as average scores, and firms that have high (or low) scores on the first interview tend to have high (or low) scores on the second interview. Thus, firms that score below two or above four on the 1-5 scale of composite management scores appear to be genuinely badly or well managed rather than extreme draws of sampling measurement error.

\section{(vi) Productivity and Competition Data}

Quantitative information on firm sales, employment, capital, materials, etc. came from the company accounts and proxy statements, and was used to calculate firm-level productivity. The details are provided in Appendix B. To measure competition we follow Nickell (1996) and Aghion et al. (2005) in using three broad measures. The first measure is the degree of import penetration in the country by three-digit industry measured as the share of total

\footnotetext{
${ }^{12} \mathrm{We}$ found no significant correlation between the number, type, and time-span of contacts before an interview was conducted and the management score. This suggests that while different managers may respond differently to the interview proposition, this does not appear to be directly correlated with their responses or the average management practices of the firm.

${ }^{13}$ This removed 33 firms from our sampling frame of 1,353 firms.
} 
imports over domestic production. This is constructed for the period 1995-9 to remove any potential contemporaneous feedback. The second is the country by three-digit industry Lerner index of competition, which is ( 1 - profits/sales), calculated as the average across the entire firm-level database (excluding each firm itself). ${ }^{14}$ Again, this is constructed for the period 1995-9 to remove any potential contemporaneous feedback. The third measure of competition is the survey question on the number of competitors a firm faces (see Appendix A2), valued zero for 'no competitors', one for 'fewer than 5 competitors', and two for ' 5 or more competitors'. ${ }^{15}$

\section{PRELIMINARY ANALYSIS AND DATA DESCRIPTION}

\section{(i) Firm Performance Outcomes and Manage- ment Practices}

A test of 'external validity' of our composite management practices score is whether it is related to better firm performance. We examine this in great detail in Bloom and Van Reenen (2006) to show that our indicator of good management is positively and significantly related to (total factor) productivity after controlling for a large number of confounding influences (capital and material inputs, size, age, skills, industry and country dummies, etc.). Figure 1 simply illustrates the non-parametric relationship between sales per employee and management practices that is positive throughout the range. The figure also shows why one should be cautious about looking solely at case studies, which would correspond to a single point on the figure. We also found that management practices are also significantly related to firm profitability, stock market values, and growth and survival rates. These are illustrated in Figure 2 that shows the means of the firm-performance measures split at the sample median of management practices.

We have to be careful in interpreting the coefficient on management (or other factors) in a production function. Since management is, at least in part, a choice variable, it is endogenous. Consequently, the coefficient on the management indicator is not the causal effect of management on productivity. Rather, we interpret the positive association as indicating that our management measure is not just 'cheap talk' but contains useful information about firm performance and appears to be measuring what we want it to measure.

\section{(ii) WLB Outcomes and WLB Practices}

First we look at whether our key measures of WLB outcomes were correlated with the practices that we might expect to improve employee WLB. If this did not turn out to be true, we would suspect that the WLB outcome measure was not really reflecting the actual events on the ground, but rather some other unobservable firm-specific characteristic. In Bloom et al. (2006) we show that the WLB outcome indicator is significantly associated with shorter hours and longer holidays (e.g. an extra 10 hours a week worked is associated with a 12 per cent lower WLB outcome score). This association is significant at the 5 per cent level even after we control for four country dummies, firm size, whether the firm is publicly listed, and firm age. Each component of the WLB practices z-score (working from home, job switching, job sharing, childcare flexibility, and childcare subsidy) is also individually significantly associated with the WLB outcome, as is the composite score. Firms which have a greater proportion of female managers are also more likely to report a higher WLB outcome. This correlation is specifically related to the proportion of female managers, not females in the workplace as a whole. The share of females in non-managerial positions is not correlated with WLB. This suggests that the correlation does not simply arise from the fact that women are more or less attracted to different firms. More likely is some combination of: (i) in firms with more female managers there is greater decision-making support for improved WLB because the balance of power is more with women; and (ii) female managers are attracted to firms with better WLB.

\section{(iii) Some Cross-country Descriptive Statistics}

Figure 3 illustrates the distribution of management scores for each country. On average, the USA has the highest management score (3.35), with Germany second (3.31), France third (3.14), and Britain

${ }^{14}$ Note that in constructing this we draw on firms in the population database, not just those in the survey.

${ }^{15}$ This question has been used by Nickell (1996) and Stewart (1990) inter alia. 
Figure 1

Non-parametric Relationship between Management z-Score and Sales per Worker

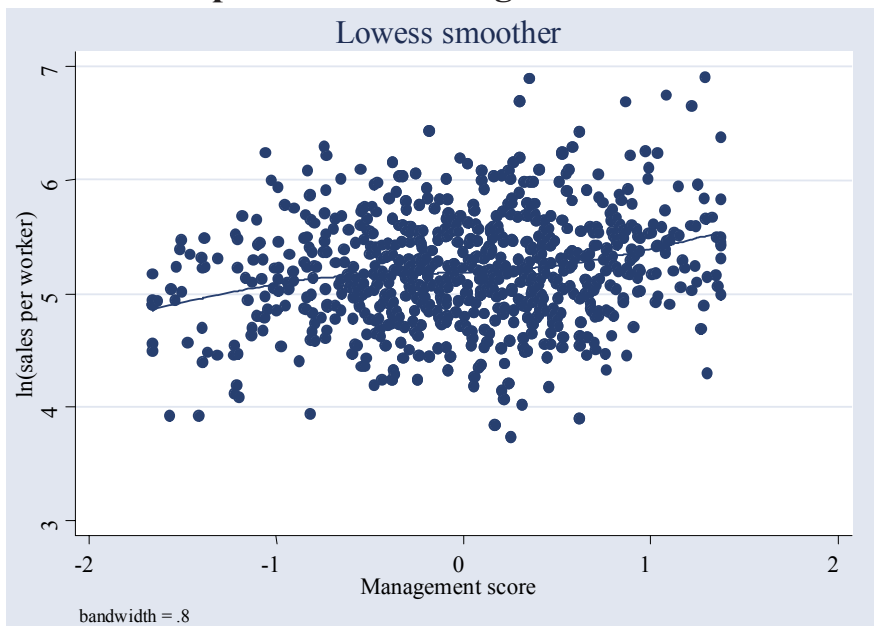

Note: This plots the locally weighted regression curve of sales per employee on the firm's average of the 18 management practices (z-scored). 732 firms included.

Figure 2

Management Scores and Firm Performance

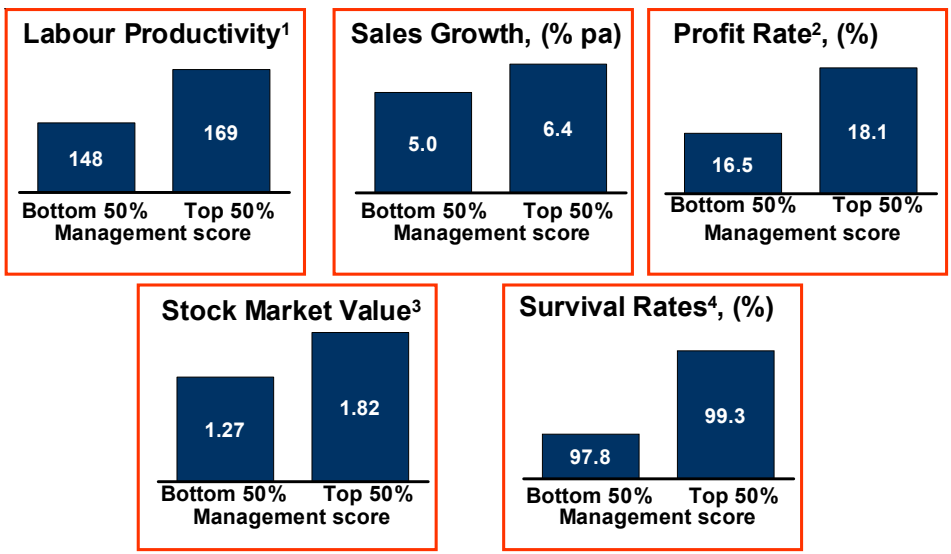

Notes: ${ }^{1} \$ ’ 000$ sales per employee at 2000 prices. ${ }^{2}$ Return on capital employed $(\%) .{ }^{3}$ Tobin's Q (\$ value of firm per $\$$ of assets), quoted firms only. ${ }^{4}$ The percentage of firms that were not bankrupt or liquidated 1 year after 2004.

Figure 3

Firm-level Average Management Scores
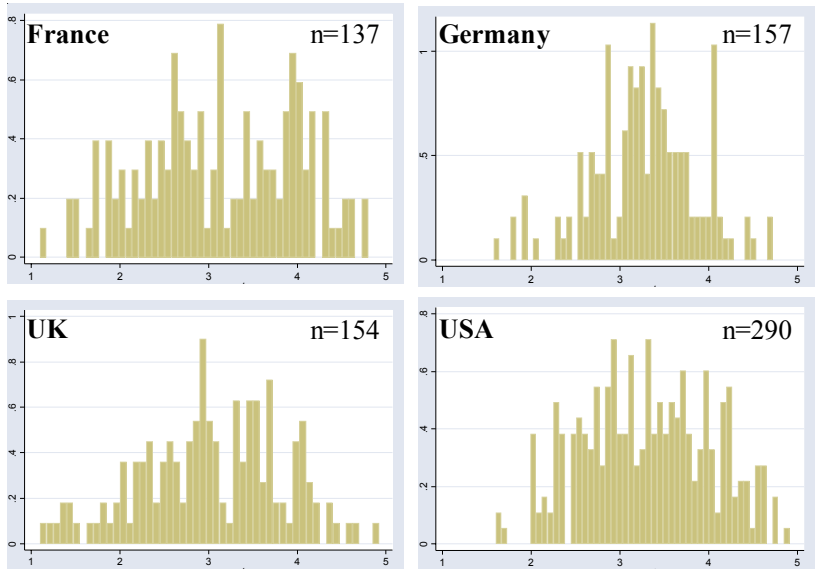

Notes: These are the distributions of the raw management scores (simple averages across all 18 practices for each firm). 1 indicates worst practice, 5 indicates best practice. 
Figure 4

\section{Cross-country Averages of Management Scores and WLB Practice Scores}

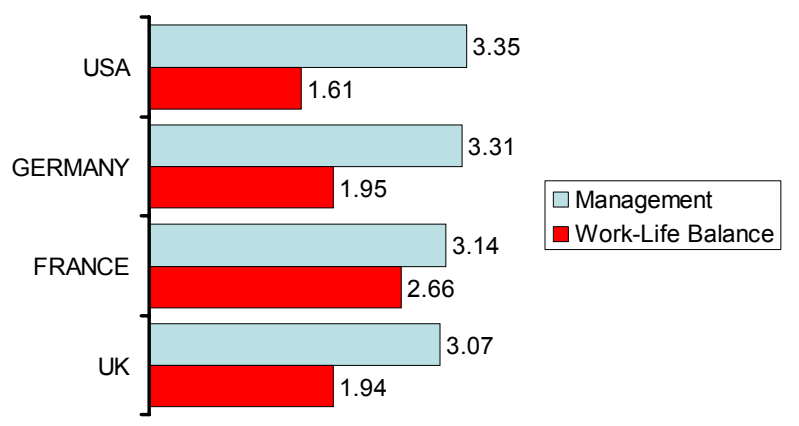

Notes: These are the country-specific averages of the raw management score (averaged at the firm level across 18 practices) and WLB practices (averaged at the firm level across 5 practices).

at the bottom (3.07). However, what is most striking about Figure 3 is the huge variation in management quality within countries that mirrors the huge variation in productivity dispersion emphasized by many recent studies (e.g. Syverson, 2004a,b). Many of the differences between countries are in the lower tails of the distribution. The USA has a thin lower tail of poorly performing firms, whereas Britain and France have a long tail of very poorly managed firms. We show below that weaker product-market competition in Europe is one of the factors accounting for this difference, but another important factor is the prevalence of family firms where management is passed on by primo geniture (to the eldest son). In Bloom and Van Reenen (2006) we show that primo geniture is strongly negatively related to good management practices and primo geniture is much more common in France and Britain than in Germany or the USA (we speculate that this is for both legal-historical and tax-related reasons). Finally, firms with a higher proportion of collegeeducated workers tend to be better managed. Taken together, primo geniture, competition, and skills account for over 60 per cent of Britain's management 'gap' with the USA (and just about all of France and Germany's gap).

An interesting feature of the WLB scores is that the cross-country pattern is very different from that of management practices (see Figure 4). The Americans score the worst on WLB practices (even though they scored the best on management quality overall) and the French appear to score the best on WLB practices, even though they ranked second from bottom on the management scores. These international comparisons can be misleading, however, as there are many other factors that could account for the cross-country patterns other than product-market competition. For this reason, our analysis focuses on looking at the differences within countries across firms.

\section{RESULTS}

\section{(i) WLB and Management}

Table 2 examines the correlation between WLB and our composite measure of good management described in the previous section. As described above, we have found this a reliable metric of the overall degree of managerial quality in the firm and the management score is strongly correlated with superior firm performance.

In the first column of Table 2, we regress WLB outcome measure on the average management score and nothing else. There is a strong positive and significant correlation between the two variables. The people management/incentives parts of the management practice scores have the strongest correlation with WLB outcomes and practices (see Bloom et al., 2006). The second column then includes the composite score of the WLB practices. This is also positive and highly significant. The third column includes a 'standard' vector of controls (firm size, firm age, country dummies, listing status, and controls for measurement error in the survey, such as interviewer fixed effects). Both variables remain positive and significant. The fourth column 
Table 2

The Links between WLB Outcome Scores, WLB Practices, and Management Best Practices

\begin{tabular}{lcccc}
\hline Dependent variable & $(1)$ & $(2)$ & $(3)$ & $(4)$ \\
& WLB & WLB & WLB & WLB \\
& outcome score & outcome score & outcome score & outcome score \\
\hline Management practices & $0.139^{* * *}$ & $0.106^{* * *}$ & $0.097^{* *}$ & $0.079^{*}$ \\
z-score & $(0.039)$ & $(0.039)$ & $(0.043)$ & $(0.044)$ \\
WLB practices z-score & & $0.219^{* * *}$ & $0.206^{* * *}$ & $0.187^{* * *}$ \\
& & $(0.037)$ & $(0.045)$ & $(0.046)$ \\
Standard controls & No & No & Yes & Yes \\
Full controls & No & No & No & Yes \\
Firms & 477 & 477 & 477 & 477 \\
\hline
\end{tabular}

Notes: In all columns, standard errors are in parentheses under coefficient estimates and allow for arbitrary heteroskedasticity. *** Significant at the 1 per cent level, ${ }^{* *}$ significant at the 5 per cent level, $*$ significant at the 10 per cent level. 'WLB outcome score' is the response to the question: 'Relative to other companies in your industry how much does your company emphasize work-life balance?', where scores are as follows: 'much less' (1); 'slightly less' (2); 'the same' (3); 'slightly more' (4); and 'much more' (5). 'Management practices z-score' is the average z-score for the 18 individual management practice scores, normalized so this measure has a mean of 0 and standard deviation of 1 . 'WLB practices z-score' is the average z-score for the five practices, 'working from home allowed', 'full-time/part-time job switching allowed', 'job sharing allowed', 'childcare flexibility', and 'childcare subsidy', normalized so this measure has a mean of 0 and standard deviation of 1 . 'Standard controls' include country dummies, $\ln$ (firm size), $\ln$ (firm age), a dummy for being listed, and the survey 'noise' controls. 'Full controls' includes the share of the workforce with degrees, the share of the workforce with MBAs, a dummy for being a subsidiary of a US multinational company, and a dummy for being a subsidiary of a non-US multinational company.

Source: Bloom et al. (2006).

includes skills and multinational status as additional controls. The skills measure - the proportion of workers with degrees - is significant at the 5 per cent level. ${ }^{16}$ Hence, firms with higher-skilled employees also tend to have better WLB practices. After including these additional controls, the management coefficient falls further and is now only significant at the 10 per cent level. Hence, while WLB practices play a strong role in influencing the WLB outcomes, management practices per se play only a weak role in influencing these, after including a full set of control variables. A final factor that appears to be important in WLB practices is the proportion of female managers - the more women are represented at the top of the hierarchy, the better is WLB. ${ }^{17}$

\section{(ii) Competition, WLB, and Management}

Having established the correlations of WLB with several factors, we now turn to the key hypotheses on competition and productivity. Table 3 examines this question in detail. We measure competition by the degree of openness to trade (columns (1) and (4)), the degree of 'excess profit' in the industry (columns (2) and (5)), or simply the number of competitors (columns (3) and (6)). The first three columns use the average management $\mathrm{z}$-score as the dependent variable, whereas the last three columns use the WLB outcome score. In all columns, we control for a number of additional variables (age, size, skills, country dummies, etc.).

\footnotetext{
${ }^{16}$ This is consistent with Osterman (1995) and Gray and Tudball (2003).

${ }^{17}$ This is consistent with Miliken et al. (1998), Guthrie and Roth (1999), Perry-Smith and Blum (2000), Martins et al. (2002), Harel et al. (2003), and Gray and Tudball (2003).
} 
Table 3

Competition Improves Management but Has No Effect on Work-Life Balance

\begin{tabular}{|c|c|c|c|c|c|c|}
\hline Estimation method & $\begin{array}{l}(1) \\
\text { OLS }\end{array}$ & $\begin{array}{l}(2) \\
\text { OLS }\end{array}$ & $\begin{array}{l}(3) \\
\text { OLS }\end{array}$ & $\begin{array}{l}(4) \\
\text { OLS }\end{array}$ & $\begin{array}{l}(5) \\
\text { OLS }\end{array}$ & $\begin{array}{l}(6) \\
\text { OLS }\end{array}$ \\
\hline Dependent variable & $\begin{array}{l}\text { Management } \\
\text { Z-score }\end{array}$ & $\begin{array}{l}\text { Management } \\
\text { Z-score }\end{array}$ & $\begin{array}{l}\text { Management } \\
\text { z-score }\end{array}$ & $\begin{array}{l}\text { WLB } \\
\text { practice } \\
\text { Z-score }\end{array}$ & $\begin{array}{l}\text { WLB } \\
\text { practice } \\
\text { Z-score }\end{array}$ & $\begin{array}{c}\text { WLB } \\
\text { practice } \\
\text { Z-score }\end{array}$ \\
\hline $\begin{array}{l}\text { Import penetration } \\
\text { (5-year lagged) }\end{array}$ & $\begin{array}{l}0.157 * * \\
(0.078)\end{array}$ & & & $\begin{array}{c}0.073 \\
(0.145)\end{array}$ & & \\
\hline $\begin{array}{l}\text { Lerner index of competition } \\
\text { (5-year lagged) }\end{array}$ & & $\begin{array}{l}1.318^{* *} \\
(0.588)\end{array}$ & & & $\begin{array}{c}0.463 \\
(0.858)\end{array}$ & \\
\hline Number of competitors & & & $\begin{array}{l}0.144 * * \\
(0.045)\end{array}$ & & & $\begin{array}{r}-0.000 \\
(0.084)\end{array}$ \\
\hline Firms & 732 & 732 & 726 & 486 & 524 & 530 \\
\hline Country controls & Yes & Yes & Yes & Yes & Yes & Yes \\
\hline
\end{tabular}

Notes: Coefficients from OLS regressions with standard errors in parentheses (robust to arbitrary heteroskedasticity and clustered by country* industry pair); single cross-section. *** Significant at the 1 per cent level, ** significant at the 5 per cent level, * significant at the 10 per cent level. 'Country controls' includes four country dummies. 'Import penetration' $=\ln (\mathrm{import} /$ production) in every country industry pair. Average over 1995-9 used. 'Lerner index of competition' constructed, as in Aghion et al. (2005), as the mean of $(1$ - profit/sales $)$ in the entire database (excluding the firm itself) for every country industry pair. 'Number of competitors' constructed from the response to the survey question on number of competitors, and is coded as 0 for 'none' ( 1 per cent of responses), 1 for 'less than 5' (51 per cent of responses), and 2 for ' 5 or more' ( 48 per cent of responses). All columns include $\ln$ (firm size), $\ln$ (firm age), a dummy for being listed, the share of workforce with degrees, the share of workforce with MBAs, a dummy for being consolidated, the survey 'noise' controls and a full set of three-digit industry dummies.

Sources: Bloom and Van Reenen (2006); Bloom et al. (2006).

There is a strong and statistically significant relationship between greater competition and superior management across all three measures of productmarket competition. By contrast, the final three columns show that there is essentially no relationship between competition and WLB outcomes..$^{18}$ In fact, the association is positive for the Lerner index and imports (when we drop the additional controls in column (4) the imports variable is positive and significant at the 10 per cent level). We conclude that although competition seems to improve management, it does not seem to reduce WLB.
We also estimated the relationship between competition and the WLB practices - working from home flexibility, job-switching flexibility, flexibility for childcare time off and childcare subsidies - and found no significant relationships. We could not find any relationship between average hours worked per week or days holidays per year and competition. So we confirm the earlier conclusion that although competition seems to improve management, it does not seem to be associated with worse WLB outcomes or practices. While higher competition appears to increase management practices by removing

\footnotetext{
${ }^{18} \mathrm{We}$ could also find no robust evidence of any negative relationship of competition on other measures of work-place intensification. For example, we ran regressions identical to those in columns (4)-(6) of Table 3, replacing WLB as the dependent variable with average managerial hours worked, average non-managerial hours worked, average holidays per year, and average sick days per year. In 10 of these 12 cases the competition measure was insignificantly different from zero. In one case competition was associated with significantly fewer hours worked (non-managerial hours regressed on the Lerner Index) and in only one of the 12 cases was competition associated with significantly more hours (non-managerial hours regressed on import penetration).
} 
Table 4

WLB Practices are Unrelated to Productivity

Countries

Estimation

Dependent variable

WLB practices z-score

Management z-score

$\ln ($ Labour)

$\ln ($ Capital)

$\ln$ (Materials)

Basic controls

Full controls

Firms
(1)

(2)

(3)

All
OLS
$\ln ($ Sales $)$
$0.048^{* *}$
$(0.023)$

$0.983^{* * *}$

$(0.018)$
All

OLS

$\ln$ (Sales)

0.034

$(0.023)$

$0.064 * * *$

(0.023)

$0.978^{* * *}$

(0.018)
All

OLS

$\ln$ (Sales)

$-0.006$

(0.018)

$0.038 * * *$

$(0.015)$

$0.500 * * *$

(0.032)

$0.122 * * *$

(0.027)

$0.370 * * *$

(0.032)

Yes

Yes

445

Notes: In all columns, standard errors are in parentheses under coefficient estimates and allow for arbitrary heteroskedasticity. ${ }^{* *}$ Significant at the 1 per cent level; ** significant at the 5 per cent level; * significant at the 10 per cent level. Basic controls include country and industry dummies, log(firm age), public listing and consolidated dummy. Full controls include industry dummies, $\log$ (firm age), public listing, per cent of workforce with degrees, per cent of employees with MBAs, the log(average hours) worked by all employees, a US multinational dummy, and a non-US multinational dummy. 'Management practices zscore' is the average z-score for the 18 individual management practice scores, normalized so this measure has a mean of 0 and standard deviation of 1 . 'WLB practices z-score' is the average z-score for the five practices, 'working from home allowed', 'full-time/part-time job switching allowed', 'job sharing allowed', 'childcare flexibility', and 'childcare subsidy', normalized so this measure has a mean of 0 and standard deviation of 1 .

Source: Bloom et al. (2006).

the worst-managed/least-productive firms from the market, it does not seem to affect WLB. This could be because (as is suggested by the next sub-section) WLB practices and productivity are essentially unrelated, so that the Darwinian selection effects of competition have no bearing on typical WLB practices. If the competition effects on management were simply because managers and workers were working harder, we would expect to have seen some impact on declining WLB and/or longer hours and shorter holidays.

\section{(iii) Productivity, WLB, and Management}

Perhaps the most important issue is the association of WLB with productivity. We address this issue in
Table 4 that shows the results from simple production functions. We must always remember the caveat that these are associations and we cannot simply infer causality. The dependent variable is the $\log$ of real sales and because we control for the factor inputs (labour, capital, and materials) the coefficient on WLB practices should be interpreted as the 'effect' on total factor (or revenue) productivity (TFP).

Column (1) of Table 4 reports the first specification that also includes country and industry dummies and basic controls (firm age, listing status, and a consolidation dummy). The association of WLB and productivity is positive and significant at the 5 per cent level. This is the kind of regression highlighted in the 
HRM literature that is often used to justify policies to introduce better WLB practices.

Column (2) of Table 4 simply conditions on our management $\mathrm{z}$-score as an additional variable. Management enters the production function with a positive and highly significant coefficient as we found in Bloom and Van Reenen (2006) and illustrated in Figures 1 and 2. The coefficient on the WLB practices variable, by contrast, falls in magnitude and is no longer significant at even the 10 per cent level. When we condition on a wider set of controls in the next column (skills, multinational status, listing, and firm age), the management variable remains positive and significant, but the WLB practices variable is now negative, albeit completely insignificant.

Table 4 suggests that the significant association of WLB with productivity is spurious and arises because WLB is correlated with an important omitted variable - good management. Firms with better management practices will tend to have both higher productivity and better WLB. This gives rise (in column (1)) to the mistaken impression that better WLB causes higher productivity.

\section{CONCLUSIONS}

Competition is often simultaneously supported as a way of increasing productivity but feared because it will make working life harder. In this paper, we have examined recent evidence from an innovative new survey tool that has generated original firm-level data on management practices and WLB. In fact, we find that the fears of a hard trade-off between improving management and improving WLB are overblown. More often than not, better management and better WLB are to be found in the same firms.
Our key finding is that tougher competition raises management quality, but does not reduce work-life balance. In other words, employees and managers end up 'working smarter' rather than just 'working harder'. From a policy perspective, this is another reason why fostering competition is to be welcomed rather than feared.

Neither did we find much evidence for the excessively optimistic supporters of WLB policies. There was a positive correlation between higher productivity and superior WLB policies. But this was seen to be spurious - once we controlled for management practices, the correlation between productivity and WLB policies was essentially zero. This suggests that much of the HRM literature has exaggerated the potential for WLB to raise productivity and that the win-win model is excessively optimistic. From a policy perspective this weakens the argument for mandatory introduction of WLB regulation, as one of the promised benefits - higher firm performance - may not materialize. From the point of view of firms, however, the absence of a strong negative association of WLB with productivity may be reassuring. Employees clearly value better WLB so this has benefits for the working environment and may justify the costs of introducing more flexibility.

In terms of management, we found that primo geniture firms (where management passes down from father to eldest son) were significantly less well managed. The UK has a very generous system of inheritance tax allowance, effectively offering 100 per cent relief for estates if business assets are passed on to family members. The USA offers no relief and Germany and France are much less generous. To the extent the UK system encourages family firms, there is a good case for eliminating or severely reducing the generosity of these reliefs. ${ }^{19}$

\footnotetext{
${ }^{19}$ For a more detailed examination of this proposal see 'Inherited Family Firms and Management Practices: The Case for Modernizing the UK's Inheritance Tax System', available at http://cep.lse.ac.uk/briefings/pa_inherited_family_firms.pdf
} 


\section{APPENDIX A1: MANAGEMENT PRACTICE INTERVIEW GUIDE AND EXAMPLE RESPONSES}

Any score from 1 to 5 can be given, but the scoring guide and examples are only provided for scores of 1 , 3 , and 5. Multiple questions are used for each dimension to improve scoring accuracy.

\section{(1) Modern manufacturing, introduction}

\section{Questions}

(a) Can you describe the production process for me?

(b) What kinds of lean (modern) manufacturing processes have you introduced? Can you give me specific examples?

(c) How do you manage inventory levels? What is done to balance the line? What is the Takt time of your manufacturing processes?

Score 1: Other than just-in-time (JIT) delivery from suppliers, few modern manufacturing techniques have been introduced, (or have been introduced in an ad hoc manner).

Example: A UK firm orders in bulk and stores the material on average 6 months before use. The business focuses on quality and not reduction of lead-time or costs. Absolutely no modern manufacturing techniques have been introduced.

Score 3: Some aspects of modern manufacturing techniques have been introduced, through informal/ isolated change programs.

Example: A supplier to the army is undergoing a full lean transformation. For 20 years, the company was a specialty supplier to the army, but now they have had to identify other competencies forcing them to compete with lean manufacturers. They have begun adopting specific lean techniques and plan to use full lean by the end of next year.

Score 5: All major aspects of modern manufacturing have been introduced (JIT, autonomation, flexible manpower, support systems, attitudes, and behaviour) in a formal way.

Example: A US firm has formally introduced all major elements of modern production. It reconfigured the factory floor based on value stream mapping and 5-S principles, broke production into cells, eliminated stockrooms, implemented Kanban, and adopted Takt time analyses to organize workflow.

\section{(2) Modern manufacturing, rationale} Questions

(a) Can you take me through the rationale to introduce these processes?

(b) What factors led to the adoption of these lean (modern) management practices?

Score 1: Modern manufacturing techniques were introduced because others were using them.

Example: A German firm introduced modern techniques because all its competitors were using these techniques. The business decision had been taken to imitate the competition.

Score 3: Modern manufacturing techniques were introduced to reduce costs.

Example: A French firm introduced modern manufacturing methods primarily to reduce costs.

Score 5: Modern manufacturing techniques were introduced to enable us to meet our business objectives (including costs).

Example: A US firm implemented lean techniques because the Chief Operating Office had worked with them before and knew that they would enable the business to reduce costs, competing with cheaper imports through improved quality, flexible production, greater innovation, and JIT delivery.

\section{(3) Process problem documentation Questions}

(a) How would you go about improving the manufacturing process itself?

(b) How do problems typically get exposed and fixed? 
(c) Talk me through the process for a recent problem.

(d) Do the staff ever suggest process improvements?

Score 1: No process improvements are made when problems occur.

Example: A US firm has no formal or informal mechanism in place for either process documentation or improvement. The manager admitted that production takes place in an environment where nothing has been done to encourage or support process innovation.

Score 3: Improvements are made in one week workshops involving all staff, to improve performance in their area of the plant.

Example: A US firm takes suggestions via an anonymous box, they then review these each week in their section meeting and decide any that they would like to proceed with.

Score 5: Exposing problems in a structured way is integral to individuals' responsibilities and resolution occurs as a part of normal business processes rather than by extraordinary effort/teams.

Example: The employees of a German firm constantly analyse the production process as part of their normal duties. They film critical production steps to analyse areas more thoroughly. Every problem is registered in a special database that monitors critical processes and each issue must be reviewed and signed off by a manager.

\section{(4) Performance tracking Questions}

(a) Tell me how you track production performance?

(b) What kind of key performance indicators (KPIs) would you use for performance tracking? How frequently are these measured? Who gets to see this KPI data?

(c) If I were to walk through your factory could I tell how you were doing against your KPIs?

Score 1: Measures tracked do not indicate directly if overall business objectives are being met. Tracking is an ad hoc process (certain processes are not tracked at all).

Example: A manager of a US firm tracks a range of measures when he does not think that output is sufficient. He last requested these reports about 8 months ago and had them printed for a week until output increased again.

Score 3: Most key performance indicators are tracked formally. Tracking is overseen by senior management.

Example: At a US firm every product is bar-coded and performance indicators are tracked throughout the production process; however, this information is not communicated to workers.

Score 5: Performance is continuously tracked and communicated, both formally and informally, to all staff using a range of visual management tools.

Example: A US firm has screens in view of every line. These screens are used to display progress to daily target and other performance indicators. The manager meets with the shop floor every morning to discuss the day past and the one ahead and uses monthly company meetings to present a larger view of the goals to date and strategic direction of the business to employees. He even stamps napkins with key performance achievements to ensure everyone is aware of a target that has been hit.

\section{(5) Performance review} Questions

(a) How do you review your KPIs?

(b) Tell me about a recent meeting

(c) Who is involved in these meetings? Who gets to see the results of this review?

(d) What are the typical next steps after a meeting?

Score 1: Performance is reviewed infrequently or in an unmeaningful way-e.g. only success or failure is noted.

Example: A manager of a US firm relies heavily on his gut feel of the business. He will review costs when he thinks there is too much or too little in the stores. He admits he is busy so reviews are infrequent. He 
also mentioned staff feel like he is going on a hunt to find a problem, so he has now made a point of highlighting anything good.

Score 3: Performance is reviewed periodically with successes and failures identified. Results are communicated to senior management. No clear follow-up plan is adopted.

Example: A UK firm uses daily production meetings to compare performance to plan. However, clear action plans are infrequently developed based on these production results.

Score 5: Performance is continually reviewed, based on indicators tracked. All aspects are followed up to ensure continuous improvement. Results are communicated to all staff.

Example: A French firm tracks all performance numbers real time (amount, quality, etc.). These numbers are continuously matched to the plan on a shift-by-shift basis. Every employee can access these figures on workstations on the shop floor. If scheduled numbers are not met, action for improvement is taken immediately.

\section{(6) Performance dialogue Questions}

(a) How are these meetings structured? Tell me about your most recent meeting.

(b) During these meetings do you find that you generally have enough data?

(c) How useful do you find problem-solving meetings?

(d) What type of feedback occurs in these meetings?

Score 1: The right data or information for a constructive discussion are often not present or conversations overly focus on data that are not meaningful. Clear agenda is not known and purpose is not stated explicitly. Example: A US firm does not conduct staff reviews. It was just 'not the philosophy of the company' to do that. The company was very successful during the last decade and therefore did not feel the need to review its performance.

Score 3: Review conversations are held with the appropriate data and information present. Objectives of meetings are clear to all participating and a clear agenda is present. Conversations do not, as a matter of course, drive to the root causes of the problems.

Example: A UK firm focuses on key areas to discuss each week. This ensures they receive consistent management attention and everyone comes prepared. However, meetings are more of an opportunity for everyone to stay abreast of current issues rather than problem-solve.

Score 5: Regular review/performance conversations focus on problem solving and addressing root causes. Purpose, agenda, and follow-up steps are clear to all. Meetings are an opportunity for constructive feedback and coaching.

Example: A German firm meets weekly to discuss performance with workers and management. Participants come from all departments (shop floor, sales, R\&D, procurement, etc.) to discuss the previous week's performance and to identify areas to improve. They focus on the cause of problems and agree topics to be followed up the next week, allocating all tasks to individual participants.

\section{(7) Consequence management}

\section{Questions}

(a) What happens if there is a part of the business (or a manager) who isn't achieving agreed upon results? Can you give me a recent example?

(b) What kind of consequences would follow such an action?

(c) Are there are any parts of the business (or managers) that seem repeatedly to fail to carry out agreed actions?

Score 1: Failure to achieve agreed objectives does not carry any consequences.

Example: At a French firm no action is taken when objectives are not achieved. The President personally intervenes to warn employees but no stricter action is taken. Cutting payroll or making people redundant because of a lack of performance is very rarely done.

Score 3: Failure to achieve agreed results is tolerated for a period before action is taken. 
Example: Management of a US firm reviews performance quarterly. That is the earliest they can react to any underperformance. They increase pressure on the employees if targets are not met.

Score 5: A failure to achieve agreed targets drives retraining in identified areas of weakness or moving individuals to where their skills are appropriate.

Example: A German firm takes action as soon as a weakness is identified. They have even employed a psychologist to improve behaviour within a difficult group. People receive ongoing training to improve performance. If this does not help they move them into other departments or even fire individuals if they repeatedly fail to meet agreed targets.

\section{(8) Target balance}

\section{Questions}

(a) What types of targets are set for the company? What are the goals for your plant?

(b) Tell me about the financial and non-financial goals?

(c) What do Corporate Headquarters (or their appropriate manager) emphasize to you?

Score 1: Goals are exclusively financial or operational.

Example: At a UK firm performance targets are exclusively operational. Specifically volume is the only meaningful objective for managers, with no targeting of quality, flexibility, or waste.

Score 3: Goals include non-financial targets, which form part of the performance appraisal of top management only (they are not reinforced throughout the rest of organization).

Example: For a French firm strategic goals are very important. They focus on market share and try to hold their position in technology leadership. However, workers on the shop floor are not aware of those targets. Score 5: Goals are a balance of financial and non-financial targets. Senior managers believe the nonfinancial targets are often more inspiring and challenging than financials alone.

Example: A US firm gives everyone a mix of operational and financial targets. They communicate financial targets to the shop floor in a way they found effective-for example telling workers they pack boxes to pay the overheads until lunchtime and after lunch it is all profit for the business. If they are having a good day the boards immediately adjust and play the 'profit jingle' to let the shop floor know that they are now working for profit. Everyone cheers when the jingle is played.

\section{(9) Target interconnection}

\section{Questions}

(a) What is the motivation behind your goals?

(b) How are these goals cascaded down to the individual workers?

(c) What are the goals of the top management team (do they even know what they are!)?

(d) How are your targets linked to company performance and their goals?

Score 1: Goals are based purely on accounting figures (with no clear connection to shareholder value). Example: A family-owned firm in France is only concerned about the net income for the year. They try to maximize income every year without focusing on any long-term consequences.

Score 3: Corporate goals are based on shareholder value but are not clearly communicated down to individuals.

Example: A US firm bases its strategic corporate goals on enhancing shareholder value, but does not clearly communicate this to workers. Departments and individuals have little understanding of their connection to profitability or value with many areas labelled as 'cost-centres' with an objective to cost-cut despite potentially disproportionately large negative impact on the other departments they serve.

Score 5: Corporate goals focus on shareholder value. They increase in specificity as they cascade through business units ultimately defining individual performance expectations.

Example: For a US firm strategic planning begins with a bottom-up approach that is then compared with the top-down aims. Multifunctional teams meet every 6 months to track and plan deliverables for each area. This is then presented to the area head that then agrees or refines it and then communicates it down to his lowest level. Everyone has to know exactly how they contribute to the overall goals or else they will not understand how important the 10 hours they spend at work every day is to the business. 


\section{(10) Target time horizon}

\section{Questions}

(a) What kind of time scale are you looking at with your targets?

(b) Which goals receive the most emphasis?

(c) How are long-term goals linked to short-term goals?

(d) Could you meet all your short-run goals but miss your long-run goals?

Score 1: Top management's main focus is on short-term targets.

Example: A UK firm has had several years of ongoing senior management changes - therefore senior managers are only focusing on how the company is doing this month versus the next, believing that longterm targets will take care of themselves.

Score 3: There are short and long-term goals for all levels of the organization. As they are set independently, they are not necessarily linked to each other.

Example: A US firm has both long- and short-term goals. The long-term goals are known by the senior managers and the short-term goals are the remit of the operational managers. Operations managers only occasionally see the longer-term goals so are often unsure how they link with the short-term goals.

Score 5: Long term goals are translated into specific short-term targets so that short-term targets become a 'staircase' to reach long-term goals.

Example: A UK firm translates all its goals - even its 5-year strategic goals-into short-term goals so it can track its performance to them. It believes that it is only when you make someone accountable for delivery within a sensible timeframe that a long-term objective will be met. It thinks it is more interesting for employees to have a mix of immediate and longer-term goals.

\section{(11) Targets are stretching}

\section{Questions}

(a) How tough are your targets? Do you feel pushed by them?

(b) On average, how often would you say that you meet your targets?

(c) Are there any targets which are obviously too easy (will always be met) or too hard (will never be met)?

(d) Do you feel that on targets all groups receive the same degree of difficulty? Do some groups get easy targets?

Score 1: Goals are either too easy or impossible to achieve; managers provide low estimates to ensure easy goals.

Example: A French firm uses easy targets to improve staff morale and encourage people. They find it difficult to set harder goals because people just give up and managers refuse to work people harder.

Score 3: In most areas, top management pushes for aggressive goals based on solid economic rationale. There are a few 'sacred cows' that are not held to the same rigorous standard.

Example: A chemicals firm has two divisions, producing special chemicals for very different markets (military, civil). Easier levels of targets are requested from the founding and more prestigious military division.

Score 5: Goals are genuinely demanding for all divisions. They are grounded in solid, economic rationale. Example: A manager of a UK firm insisted that he has to set aggressive and demanding goals for everyone- even security. If they hit all their targets he worries he has not stretched them enough. Each KPI is linked to the overall business plan.

\section{(12) Performance clarity}

\section{Questions}

(a) What are your targets (i.e. do they know them exactly)? Tell me about them in full.

(b) Does everyone know their targets? Does anyone complain that the targets are too complex?

(c) How do people know about their own performance compared to other people's performance?

Score 1: Performance measures are complex and not clearly understood. Individual performance is not made public. 
Example: A German firm measures performance per employee based on differential weighting across 12 factors, each with its own measurement formulas (e.g. individual versus average of the team, increase on prior performance, thresholds, etc.). Employees complain the formula is too complex to understand, and even the plant manager could not remember all the details.

Score 3: Performance measures are well defined and communicated; performance is public in all levels but comparisons are discouraged.

Example: A French firm does not encourage simple individual performance measures as unions pressure them to avoid this. However, charts display the actual overall production process against the plan for teams on a regular basis.

Score 5: Performance measures are well defined, strongly communicated, and reinforced at all reviews; performance and rankings are made public to induce competition.

Example: At a US firm self-directed teams set and monitor their own goals. These goals and their subsequent outcomes are posted throughout the company, encouraging competition in both target setting and achievement. Individual members know where they are ranked which is communicated personally to them bi-annually. Quarterly company meetings seek to review performance and align targets.

\section{(13) Managing human capital Questions}

(a) Do senior managers discuss attracting and developing talented people?

(b) Do senior managers get any rewards for bringing in and keeping talented people in the company?

(c) Can you tell me about the talented people you have developed within your team? Did you get any rewards for this?

Score 1: Senior management does not communicate that attracting, retaining, and developing talent throughout the organization is a top priority.

Example: A US firm does not actively train or develop its employees, and does not conduct performance appraisals or employee reviews. People are seen as a secondary input to the production.

Score 3: Senior management believes and communicates that having top talent throughout the organization is a key way to win.

Example: A US firm strives to attract and retain talent throughout the organization, but does not hold managers individually accountable for the talent pool they build. The company actively cross-trains employees for development and challenges them through exposure to a variety of technologies.

Score 5: Senior managers are evaluated and held accountable on the strength of the talent pool they actively build.

Example: A UK firm benchmarks human resources practices at leading firms. A cross-functional HR excellence committee develops policies and strategies to achieve company goals. Bi-monthly directors' meetings seek to identify training and development opportunities for talented performers.

\section{(14) Rewarding high-performance}

\section{Questions}

(a) How does your appraisal system work? Tell me about the most recent round?

(b) How does the bonus system work?

(c) Are there any non-financial rewards for top performers?

(d) How does your reward system compare to your competitors?

Score 1: People within our firm are rewarded equally irrespective of performance level.

Example: An East German firm pays its people equally and regardless of performance. The management said to us 'there are no incentives to perform well in our company'. Even the management is paid an hourly wage, with no bonus pay.

Score 3: Our company has an evaluation system for the awarding of performance-related rewards.

Example: A German firm has an awards system based on three components: the individual's performance, shift performance, and overall company performance. 
Score 5: We strive to outperform the competitors by providing ambitious stretch targets with clear performance-related accountability and rewards.

Example: A US firm sets ambitious targets, rewarded through a combination of bonuses linked to performance, team lunches cooked by management, family picnics, movie passes, and dinner vouchers at nice local restaurants. They also motivate staff to try by giving awards for perfect attendance, best suggestion, etc.

\section{(15) Removing poor performers}

\section{Questions}

(a) If you had a worker who could not do his job what would you do? Could you give me a recent example?

(b) How long would underperformance be tolerated?

(c) Do you find any workers who lead a sort of charmed life? Do some individuals always just manage to avoid being fixed/fired?

Score 1: Poor performers are rarely removed from their positions.

Example: A French firm had a supervisor who was regularly drinking alcohol at work but no action was taken to help him or move him. In fact, no employee had ever been laid off in the factory. According to the plant manager, HR 'kicked up a real fuss' whenever management wanted to get rid of employees, and told managers their job was production not personnel.

Score 3: Suspected poor performers stay in a position for a few years before action is taken.

Example: For a German firm it is very hard to remove poor performers. The management has to prove at least three times that an individual underperformed before they can take serious action.

Score 5: We move poor performers out of the company or to less critical roles as soon as a weakness is identified.

Example: At a US firm, the manager fired four people during last couple of months due to underperformance. They continually investigate why and who are underperforming.

\section{(16) Promoting high performers}

\section{Questions}

(a) Can you rise up the company rapidly if you are really good? Are there any examples you can think of?

(b) What about poor performers - do they get promoted more slowly? Are there any examples you can think of?

(c) How would you identify and develop (i.e. train) your star performers?

(d) If two people both joined the company 5 years ago and one was much better than the other would he/ she be promoted faster?

Score 1: People are promoted primarily upon the basis of tenure.

Example: A UK firm promotes based on an individual's commitment to the company measured by experience. Hence, almost all employees move up the firm in lock step. Management was afraid to change this process because it would create bad feeling among the older employees who were resistant to change.

Score 3: People are promoted upon the basis of performance.

Example: A US firm has no formal training programme. People learn on the job and are promoted based on their performance on the job.

Score 5: We actively identify, develop, and promote our top performers.

Example: At a UK firm each employee is given a red light (not performing), amber light (doing well and meeting targets), a green light (consistently meeting targets very high performer), and a blue light (high performer capable of promotion of up to two levels). Each manager is assessed every quarter based on his succession plans and development plans for individuals. 


\section{(17) Attracting human capital} Questions

(a) What makes it distinctive to work at your company as opposed to your competitors?

(b) If you were trying to sell your firm to me how would you do this (get them to try to do this)?

(c) What don't people like about working in your firm?

Score 1: Our competitors offer stronger reasons for talented people to join their companies.

Example: A manager of a firm in Germany could not give an example of a distinctive employee proposition and (when pushed) thinks the value proposition is worse than most of its competitors. He thought that people working at the firm 'have drawn the short straw'.

Score 3: Our value proposition to those joining our company is comparable to those offered by others in the sector.

Example: A US firm seeks to create a value proposition comparable to its competitors and other local companies by offering competitive pay, a family atmosphere, and a positive presence in the community. Score 5: We provide a unique value proposition to encourage talented people to join our company above our competitors.

Example: A German firm offers a unique value proposition through development and training programmes, family culture in the company, and very flexible working hours. It also strives to reduce bureaucracy and seeks to push decision-making down to the lowest levels possible to make workers feel empowered and valued.

\section{(18) Retaining human capital \\ Questions}

(a) If you had a star performer who wanted to leave what would the company do?

(b) Could you give me an example of a star performer being persuaded to stay after wanting to leave?

(c) Could you give me an example of a star performer who left the company without anyone trying to keep them?

Score 1: We do little to try and keep our top talent.

Example: A German firm lets people leave the company if they want. They do nothing to keep those people since they think that it would make no sense to try to keep them. Management does not think they can keep people if they want to work somewhere else. The company also will not start salary negotiations to retain top talent.

Score 3: We usually work hard to keep our top talent.

Example: If management of a French firm feels that people want to leave the company, they talk to them about the reasons and what the company could change to keep them. This could be more responsibilities or a better outlook for the future. Managers are supposed to 'take the pulse' of employees to check satisfaction levels.

Score 5: We do whatever it takes to retain our top talent.

Example: A US firm knows who its top performers are and if any of them signal an interest to leave it pulls in senior managers and even corporate HQ to talk to them and try and persuade them to stay. Occasionally they will increase salary rates if necessary and if they feel the individual is being underpaid relative to the market. Managers have a responsibility to try to keep all desirable staff. 


\section{APPENDIX A2: HUMAN RESOURCES INTERVIEW GUIDE}

Run in parallel to the management survey but targeted at the HR department

Workforce characteristics

\section{Data field}

Total number of employees

$\%$ with university degree

$\%$ with MBA

Average age of employees

$\%$ of employees

Average training days per year

Average hours worked per week (including overtime, excluding breaks)

Average holidays per year

Average days sick-leave

$\%$ part-time

$\%$ female

$\%$ employees abroad

$\%$ union membership

Are unions recognized for wages bargaining [yes/no]

WLB outcome measure:

\section{Question}

Relative to other companies in your industry

how much does your company emphasize

work-life balance?

WLB practices:

\section{Question}

If an employee needed to take a day off at short notice due to child-care problems or their child was sick how do they generally do this?

\section{What entitlements are there to the following}

Working at home in normal working hours?

Switching from full-time to part-time work?

Job-sharing schemes?

Financial subsidy to help pay for childcare?

Organizational Characteristics

\section{Question}

Who decides the pace of work?

Who decides how tasks should be allocated?

Do you use self-managing teams?

\author{
Breakdown \\ (all employees) \\ (all employees) \\ (all employees) \\ (all employees) \\ (managerial/non-managerial) \\ (managerial/non-managerial) \\ (managerial/non-managerial) \\ (all employees) \\ (all employees) \\ (managerial/non-managerial) \\ (managerial/non-managerial) \\ (all employees) \\ (all employees) \\ (all employees)
}

Response choice (all employees) [much less/slightly less/the same/ slightly more/much more]

\section{Response choice (managerial/non-managerial) \\ [Not allowed/Never Been Asked/ Take as leave without pay/Take annual leave/Take as sick leave] \\ Breakdown \\ (managerial/non-managerial) \\ (managerial/non-managerial) \\ (managerial/non-managerial) \\ (managerial/non-managerial)} time off but make it up later/Take as

Response choice (all employees) [exclusively workers/mostly workers/ equally/mostly managers/exclusively managers]

[exclusively workers/mostly workers/ equally/mostly managers/exclusively managers]

[v.heavily/heavily/moderately/slightly/ none] 
Market and firm questions:

No. of competitors

No. of hostile take-over bids in last 3 years

Interviewer's assessment of the scoring reliability

$1-5$ scoring system calibrated according to:

$1=$ interviewee did not have enough expertise for interview to be valuable; I have significant doubts about most of the management dimensions probed;

$3=$ interviewee had reasonable expertise; on some dimensions I am unsure of scoring;

$5=$ interviewee had good expertise, I am confident that the score reflects management practices in this firm.
Response choice

[none/less than $5 / 5$ or more]

[none/one/more than one ]

\section{APPENDIX B: DATA}

\section{Sampling Frame Construction}

Our sampling frame was based on the Amadeus dataset for Europe (UK, France, and Germany) and the Compustat dataset for the USA. These all have information on company accounting data. We chose firms whose principal industry was in manufacturing and who employed (on average between 2000 and 2003) no fewer than 50 employees and no more than 10,000 employees. We also removed any clients of the consultancy firm we worked with from the sampling frame (33 out of 1,353 firms).

Our sampling frame is reasonably representative of medium-sized manufacturing firms. The European firms in Amadeus include both private and public firms whereas Compustat only includes publicly listed firms. There is no US database with privately listed firms with information on sales, labour, and capital. Fortunately, there is a much larger proportion of firms listed on the stock exchange in the USA than in Europe, so we were able to go substantially down the size distribution using Compustat. Nevertheless, the US firms in our sample are slightly larger than those of the other countries, so we were always careful to control for size and public listing in the analyses. Furthermore, when estimating production functions we could allow all coefficients to be different on labour, capital, materials, and consolidation status by country.

Another concern is that we conditioned on firms where we have information on sales, employment, and capital. These items are not compulsory for firms below certain size thresholds, so disclosure is voluntary to some extent for the smaller firms. Luckily, the firms in our sampling frame (over 50 workers) are past the threshold for voluntary disclosure (the only exception is for capital in Germany).

We achieved a response rate of 54 per cent from the firms that we contacted - a very high success rate given the voluntary nature of participation. Respondents were not significantly more productive than non-responders. French firms were slightly less likely to respond than firms in the other three countries and all respondents were significantly larger than non-respondents. Apart from these two factors, respondents seemed randomly spread around our sampling frame.

\section{Firm-level Data}

Our firm accounting data on sales, employment, capital, profits, shareholder equity, long-term debt, market values (for quoted firms), and wages (where available) came from Amadeus (France, Germany, and the UK) and Compustat (USA). For other data fields we did the following:

Materials: In France and Germany these are line items in the accounts. In the UK they were constructed by deducting the total wage bill from the cost of goods sold. In the USA they were constructed following the method in Bresnahan et al. (2002). We start with costs of good sold (COGS), less depreciation (DP), less labour costs (XLR). For firms who do not report labour expenses expenditures we use average wages and benefits at the four-digit industry level (Bartelsman et al. (2000) until 1996 and then Census Average Production Worker Annual Payroll by four-digit NAICS code) 
and multiply this by the firm's reported employment level. This constructed measure is highly correlated at the industry level with materials. Obviously there may be problems with this measure of materials (and therefore value added), which is why we check robustness to measures without materials.

\section{Industry-level Data}

This comes from the OECD STAN database of industrial production. This is provided at the country ISIC Rev. 3 level and is mapped into US SIC (1997) three (which is our common industry definition in all four countries).

\section{REFERENCES}

Aghion, P., Bloom, N., Blundell, R., Griffith, R., and Howitt, P. (2005), 'Competition and Innovation: An Inverted U Relationship', Quarterly Journal of Economics, 120, 701-28.

Arthur, M. (2003), 'Share Price Reactions to Work-Family Initiatives: An Institutional Perspective', Academy of Management Journal, 46, 497-505.

Bartel, A., Ichniowski, C., and Shaw, K. (2004), 'Using “Insider Econometrics” to Study Productivity', American Economic Review, 94, 217-23.

Bartelsman, E., Becker, R., and Gray, W. (2000), The NBER Manufacturing Productivity Database, Cambridge, MA, NBER.

Bertrand, M., and Mullainathan, S. (2001), 'Do People Mean What they Say? Implications for Subjective Survey Data', American Economic Review Papers and Proceedings, 91, 67-72.

Black, S., and Lynch, L. (2001), 'How to Compete: The Impact of Workplace Practices and Information Technology on Productivity', Review of Economics and Statistics, 83, 434-45.

Bloom, N., and Van Reenen, J. (2006), 'Measuring and Explaining Management Practices across Firms and Nations', Centre for Economic Performance Discussion Paper No. 716.

- Kretschmer, T., and Van Reenen, J.(2006), ‘Work Life Balance, Management Practices and Productivity’, Centre for Economic Performance Working Paper Special Paper No. 16.

Bresnahan, T., Brynjolfsson, E., and Hitt, L. (2002), 'Information Technology, Workplace Organization and the Demand for Skilled Labor: Firm-level Evidence', Quarterly Journal of Economics, 339-76.

Budd, J., and Mumford, K. (forthcoming), 'Family-friendly Work Practices in Britain: Availability and Effective Coverage', Human Resource Management, forthcoming.

Delaney, J., and Huselid, M. (1996), 'The Impact of Human Resource Management Practices on Perceptions of Organizational Performance', Academy of Management Journal, 39, 949-69.

Gray, H. (2002), 'Family-friendly Working: What a Performance! An Analysis of the Relationship between the Availability of Family Friendly Policies and Establishment Performance', CEP Discussion Paper No. 529.

Gray, M., and Tudball, J. (2003), 'Family-friendly Work Practices: Differences within and between Workplaces', Journal of Industrial Relations, 45, 269-91.

Guthrie, J. (2001), 'High-involvement Work Practices, Turnover, and Productivity: Evidence from New Zealand', Academy of Management Journal, 44, 180-90.

- Roth, L. (1999), 'The State, Courts and Maternity Policies in US Organizations: Specifying Institutional Arrangements', American Sociological Review, 64, 41-63.

- Spell, C., and Nyamori, R.(2002), 'Correlates and Consequences ofHigh Involvement Work Practices: The Role of Competitive Strategy’, International Journal of Human Resource Management, 13, 183-97.

Harel, G., Tzafrir, S., and Baruch, Y.(2003), 'Achieving Organizational Effectiveness through Promotion of Women into Managerial Positions: HRM Practice Focus', International Journal of Human Resource Management, 14, 247-63.

Huselid, M., Jackson, S., and Schuler, R. (1997), 'Technical and Strategic Human Resource Management Effectiveness as Determinants of Firm Performance', Academy of Management Journal, 40, 171-88.

Ichniowski, C., Shaw, K., and Prenushi, G. (1997), 'The Effects of Human Resource Management: A Study of Steel Finishing Lines', American Economic Review, 87, 291-313.

Konrad, A., and Mangel, R. (2000), 'The Impact of Work-Life Programs on Firm Productivity', Strategic Management Journal, 21, 1225-37. 
Lee, J., and Miller, D. (1999), 'People Matter: Commitment to Employees, Strategy and Performance in Korean Firms', Strategic Management Journal, 20, 579-93.

Manski, C. (2004), 'Measuring Expectations', Econometrica, 72, 1329-76.

Martins, L., Eddleston, K., and Veiga, J. (2002), 'Moderators of the Relationship between Work-Family Conflict and Career Satisfaction', Academy of Management Journal, 45, 399-409.

Miliken, F., Martins, L., and Morgan, H. (1998), 'Explaining Organizational Responsiveness to Work-Family Issues: The Role of Human Resource Executives as Issue Interpreters', Academy of Management Journal, 41, 58092.

Nickell, S. (1996), 'Competition and Corporate Performance', Journal of Political Economy, 104, 724-46.

Osterman, P. (1995), 'Work/Family Programs and the Employment Relationship', Administrative Science Quarterly, 40, 681-700.

Perry-Smith, J., and Blum, T. (2000), 'Work-Family Human Resource Bundles and Perceived Organizational Performance', Academy of Management Journal, 43, 1107-17.

Stewart, M (1990), 'Union Wage Differentials, Product Market Influences and the Division of Rents', The Economic Journal, 100, 1122-37.

Syverson, C. (2004a), 'Market Structure and Productivity: A Concrete Example', Journal of Political Economy, 112, $1181-222$.

- $\quad$ (2004b), 'Product substitutability and Productivity Dispersion', Review of Economics and Statistics, 86, 53450.

Youndt, M., Snell, S., Dean, J., and Lepak, D. (1996), 'Human Resource Management, Manufacturing Strategy, and Firm Performance', Academy of Management Journal, 39, 836-66. 